\title{
THERMAL COMFORT SIMULATION ON CIK DITIRO CORRIDOR
}

\author{
Septian Eka Prayoga ${ }^{1 *}$, Arif Kusumawanto ${ }^{2}$ \\ ${ }^{1 *}$ Graduate Student Desain Kawasan Binaan Gajah Mada University, Yogyakarta \\ ${ }^{2}$ Department of Architecture, Gadjah Mada University, Yogyakarta \\ *Corresponding author; Email: septianekaprayoga@gmail.com
}

\begin{abstract}
Surface materials that turn into hard surface material and lack of vegetations are some of the effects of rapid development that can affect the micro climate in urban areas. This happened on Cik Ditiro corridor in the city of Yogyakarta which had quite dense activities, this was marked by various functions of land use and human activities throughout the day. The method is simulation method that uses the EnviMET 4.0 software and the empirical measurements. This method is to simulate the value of each climate variable in existing conditions and ideal conditions. The results of this research show that the condition of the Cik Ditiro corridor still belongs to the heat which is uncomfortable thermal conditions. Recommendations result of this research is to make better thermal comfort on corridor. The result of this research to give recommendations in terms of improving better for thermal comfort.
\end{abstract}

Keywords: Corridor of Urban; thermal comfort; EnviMET.

\section{INTRODUCTION}

The rapid development that often occurs in an urban area can affect microclimate conditions. Microclimate is a climate in a limited space such as buildings, roads, spaces and regions (Koerniawan, 2000). There are several factors that contribute to changes in the urban microclimate such as buildings, roads, hardscapes, the proportion of vegetation, open space, etc. (Anupriya, 2016). The changing conditions of urban microclimates will affect comfort, especially thermal comfort for humans. This thermal comfort is indispensable for humans in conducting all day activities outdoors or indoors.

In this study, the case study location was taken at Cik Ditiro Corridor, Yogyakarta City, DIY. This corridor has a length of $\pm 1.2 \mathrm{KM}$, extending from Cik Ditiro Street to Suroto Street in Kotabaru, Yogyakarta. This corridor has a garden city concept from the time of Dutch East Indies in 1917 designed by Thomas Karsten. Sir Ebenezer Howard discovered the garden city concept in 1898 that is one of the alternative solutions in the planning of a city surrounded by natural green areas where the proportion of its city building is balanced with the environment. This garden City concept has several principles that one of them has many vegetation on the left-right side of the roadway.

However, the last few years of Cik Ditiro's corridor have some changes to the type of surface material such as the more dominant asphalt and paving material as well as reduced number of vegetation caused by rapid development. According to (Mingyi, 2008), it states that the corridors which road surfaces are largely covered by hard surface materials such as asphalt, concrete and so on have large thermal capacities and impact on urban microclimate compared with Corridors that are largely covered by vegetation. Because the changes that occur in the Cik Ditiro corridor make this corridor has two different characters, on Cik Ditiro street the identity of the garden City is reduced, while on Suroto street still retain the identity of the Garden City. So that, each of these two characters has different levels of thermal comfort.

Moreover, tropical climate country has the most common problems such as high temperature and solar heat radiation during the day (Karyono, 2001). The problem in this tropical climate country can influence the thermal comfort within this area of the corridor and can influence the users of corridors such as pedestrians. Pedestrian activity and outdoor activities in Cik Ditiro corridor are quite dense. In addition, a variety of functions of land use that are close to each other such as education facilities, public facilities, health facilities, office, services, commercial and residential become one of the factors caused dense activity on this corridor. So that the thermal comfort of Cik Ditiro corridor is very necessary to support human beings during all day activities outside the room.

\section{THERMAL COMFORT}

Definition of thermal comfort according to ASHRAE (American Society of Heating, Refrigerating, and Air-conditioning Engineers) is a condition where there is satisfaction to the surrounding thermal comfort. 
According to (Fanger, 1970), states that the factors affecting thermal comfort are air temperature, humidity, wind speed and temperature of radiation, the insulation of clothing and human activity. In the international standard of thermal comfort (ISO 7730:1994) states that the factors affecting thermal comfort are grouped into two namely climate factors (air temperature, radiation, humidity, wind speed), and personal factors such as human body metabolism, and clothing insulation.

Air temperature is one of the factors affecting thermal comfort in the urban area. According to United State Department of Energy (2009), there are several factors that lead to increased air temperature in an area such as the thermal properties of building materials, the building material radiation, the heat waste from the vehicle (anthropogenic factor), the geometric effect of urban design and the change of land surface cover. Indonesia is located in a tropical climate that has high intensity radiation temperature. From the temperature of this solar heat, radiation will affect air temperature and impact on the human thermal comfort in the area. The amount of solar radiation, either received by elements in the area directly or indirectly, will cause the temperature of the element to increase. So that the increased air temperature of the element of an area will affect the temperature of the surrounding environment.

In addition, the air temperature and temperature of the solar radiation, humidity also affect the thermal comfort of an area. According to Stevanus (2015), humidity can affect the comfort directly by controlling the rate of evaporation of sweat, other than that the humidity also affects the Earth's ability to accept insolation.

Wind speeds also affect the thermal comfort of an area. According to Kusumawanto (2005), wind is a direct variable that affects the effective temperature value, in addition to humidity and temperature. So that the wind is one of the microclimate that can be controlled and produce significant changes in the thermal condition of the area, and directly affect the thermal comfort. If the wind blows very tightened in addition to affecting thermal discomfort can also be catastrophic. Conversely, if the wind blows slowly then it can affects the thermal comfort.

Beside the climate factors, personal factors also affect the thermal comfort of an area. One of the personal factors is the metabolic heat rate (human activity). This metabolic heat rate has two important roles such as heat loss and heat gain (Stevanus, 2015). This Heat loss will provide a cold impact on the human body if it is excessive. While the heat gain will provide a hot impact on the human body if excessive.
Each human activity has a different (MET) value. If the activity is heavier, the value (Met) is higher, and otherwise if the activities is lighter, the smaller the value (MET).

Beside the metabolic heat rates, clothing insulation is also a personal factor that affects the thermal comfort. Humans can adapt to the surrounding climate by way of clothing, if it is hot then humans will reduce the layer of clothing or otherwise if it is humans feels cold then it will add layers of clothing to warm the body. Therefore, that clothing is the thing that affects the body's sensitivity to the surrounding climate variation. The unit (clo) determines value of the clothing insulation, so that each outfit has a different value (clo). The thicker a clothing then the value (clo) will be bigger, and otherwise the thinner a clothing then the value (clo) is getting smaller.

\section{PREDICTED MEAN VOTE}

In this study, to measure thermal comfort in Cik Ditiro corridor using PMV (Predicted Mean Vote) value. The PMV (Predicted Mean Vote) value was introduced and developed by P.O Fanger from Technical University of Denmark. The value of PMV (Predicted Mean Vote) is the measuring instrument used to indicate cold to hot sensation that can be felt by human by using a scale of 7 points starting from the number -3 (cold) to +3 (hot) and the ideal value of comfortable thermal located at number 0 (neutral). This PMV (Predicted Mean Vote) value is derived from the six-factor calculation results affecting thermal comfort such as climate factors (air temperature, relative humidity, wind speed and mean radiant temperature) and personal factors (clothing insulation and metabolic heat rate).

Table 1. Predicted Mean Vote (PMV) Index

\begin{tabular}{cc}
\hline PMV & Thermal sensation \\
\hline $\mathbf{- 3}$ & Very Cold \\
$\mathbf{- 2}$ & Cool \\
$\mathbf{- 1}$ & Slightly Cool \\
$\mathbf{0}$ & Neutral \\
$\mathbf{+ 1}$ & Slightly Warm \\
$\mathbf{+ 2}$ & Hot \\
$\mathbf{+ 3}$ & Very Hot \\
\hline
\end{tabular}

Source: ISO 7740-1994

\section{THERMAL CONTROL FOR AREA}

Climate factors are one of the obstacles factor when design an area to reach thermal comfort, considering that Indonesia country climate is a humid tropical climate. One of the common humid tropical climate constraints is the high rainfall in the rainy 
season, high temperatures in the dry season due to the high heat radiation so that can interfere with humans when outdoors activities. According to (Wong Nyuk Hien, 2016), There are three urban elements that affect the micro-thermal of the area namely buildings, hard surface area (paving or asphalt) and green areas.

In addition, some researches mention that vegetation has an important role in modifying the micro-climate in the urban area such as to hold solar heat radiation so as to reduce air temperature rise and to fix thermal comfort, creating clean air, reduce noise and air pollution in the urban area (Karyono, 2013; Anupriya, 2016; Winansih, 2015; Koerniawan, 2017; Lee, 2018; Adedeji, 2011).

According to EPA (Environmental Protection Agency), it also states that increased the number of tree as well as using reflective paving in addition to lowering the air temperature can also create clean air, and increased comfort and health for human. It can be interpreted that the color and material on the paving can affect the absorption of solar radiation that causes increase the ambient air temperature. Dark color has a higher absorption of heat radiation than light color.

\section{RESEARCH METHODS}

This study examines the optimization of thermal comfort on the corridor space to support the corridor users especially pedestrians for all-day activities. To generate good quality thermal comfort in this corridor, the method used in research is by simulation method using EnviMET software and empirical measurement, to show results of thermal quality and thermal analysis by using measured data in locations using certain measuring instruments.

There are several steps in this research method starting from the data collection and climate condition of Yogyakarta that specifically refers to Cik Ditiro corridor. Furthermore, site observations, documenting locations and variables to be examined include the dimensions of physical elements of building materials, road materials, building distances, pedestrian ways dimensions, pedestrian ways materials, road widths, height and width vegetation based on vegetation type, pedestrian activity, air temperature, humidity, wind speed and wind direction.

The next step is modeling simulation and thermal data analysis in existing conditions of Cik Ditiro corridor. This modeling simulation uses Envi MET software to find out the existing condition of the corridor, and then generate thermal data such as temperature, humidity, wind speed, and thermal comfortable values. After analyze the existing condition of the corridor then the next thing set the corridor model using the same software to get the ideal model that can be fix the thermal comfort in Cik Ditiro corridor. Afterwards, analyze the changes in thermal data in existing conditions and ideal conditions on the Cik Ditiro corridor. Then the result of the data comparison of the thermal comfort value can be used as a basic reference for designing the corridor, so that can reach thermal comfort for users of the Cik Ditiro corridor especially pedestrians.

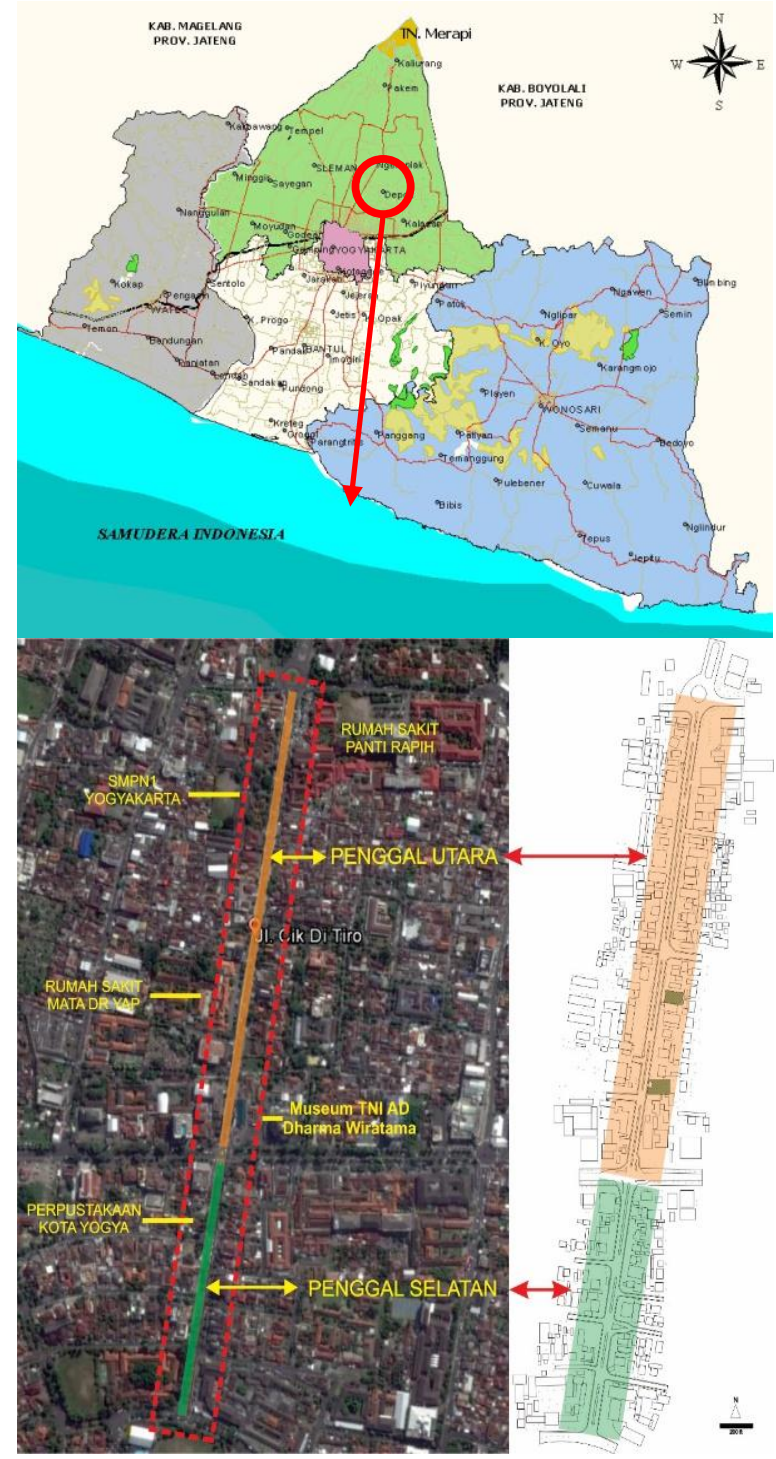

Fig.1. Research Location.

\section{ANALYSIS AND DISCUSSION}

To simulate existing condition in Cik Ditiro corridor, there are some data needed namely building materials, building height, distance between buildings, road material, pedestrian ways dimension, pedestrian ways material, road width, height and width vegetation, pedestrian activity and clothing insulation from pedestrians. 


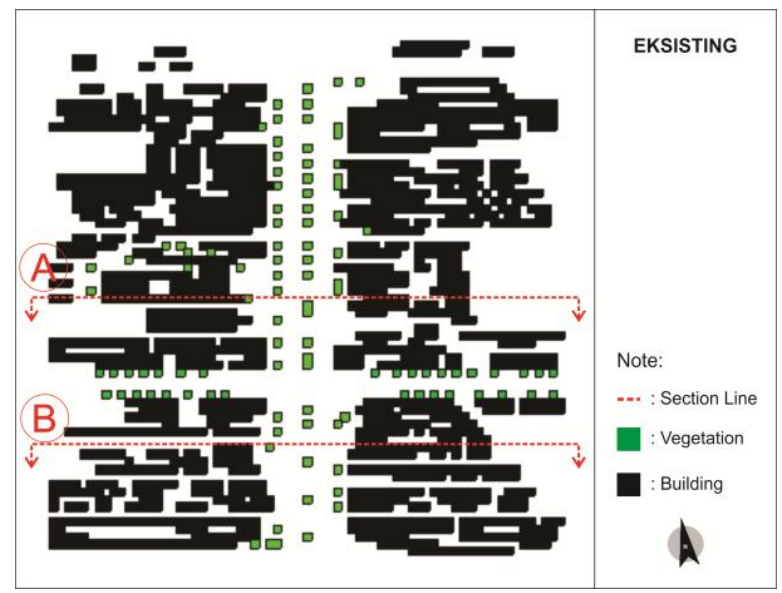

Fig. 2. Top View of the Existing Model Cik Ditiro Corridor.

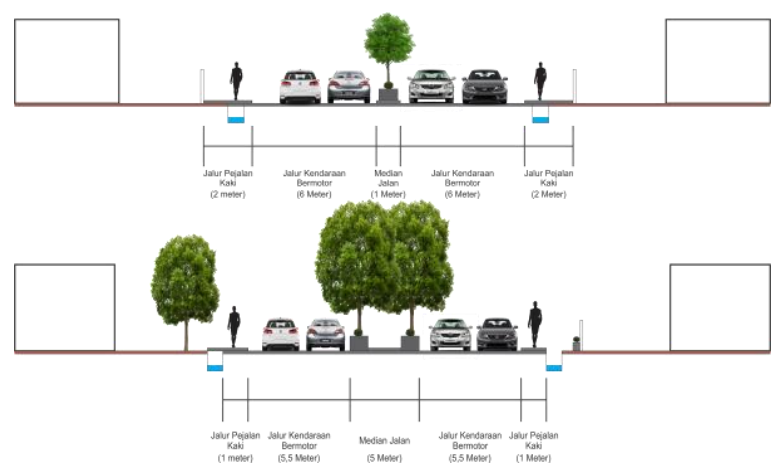

Fig. 3. Section of Exisiting Model Cik Ditiro Corridor Nothern Part (Top) and Southern Part (Bottom)

If it viewed based on existing conditions in Cik Ditiro corridor, the surface material in the corridor such as asphalt and paving blocks are more dominant than the vegetation. Then the height of the building in Cik Ditiro corridor consists of 1 to 6 floors and the most dominant height of the building in this corridor is 1 to 2 floors. For the distance between buildings in existing condition of northern part (Cik Ditiro street) tend to be tightly rather than existing condition in the southern part (Suroto street). The roadway width in the northern part is wider $0.5-1$ meter compared to the southern part. Furthermore, for the number of vegetation in the northern part less compared with the southern part that still strong identity as an area with the concept of Garden City.

As the basis of simulation needed, is a climate area data of existing conditions. The climate data needed is air temperature, humidity, and wind speed and wind direction. In this study, the climate data used is secondary data that obtained from the meteorological station of Adi Sutjipto, Yogyakarta. Based on secondary data, the city of Yogyakarta has an average air temperature of $27^{\circ} \mathrm{C}$ and an average air humidity of $82 \%$. The wind generally blows from a direction of $220^{\circ}$ or Southwest with an average wind speed of 3 knots at a height of 10 meters from the ground surface. But used in the simulation of existing conditions using data as of 6 March 2018 from 9 a.m. to $3 \mathrm{pm}$ adjusted to the site observation with an average air temperature of $26^{\circ} \mathrm{C}$, average air humidity $85 \%$, and wind speed Average of 3 knots with the dominant wind direction from the north.
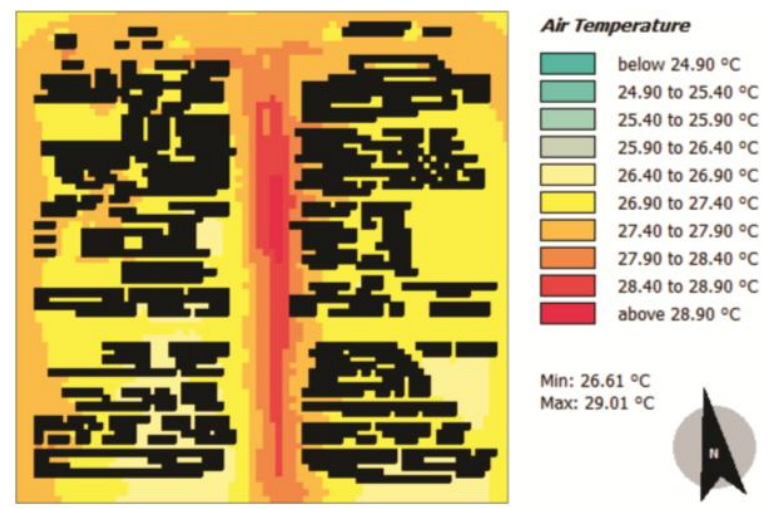

Fig. 4. Air Temperature Simulation Results in Existing Conditions.

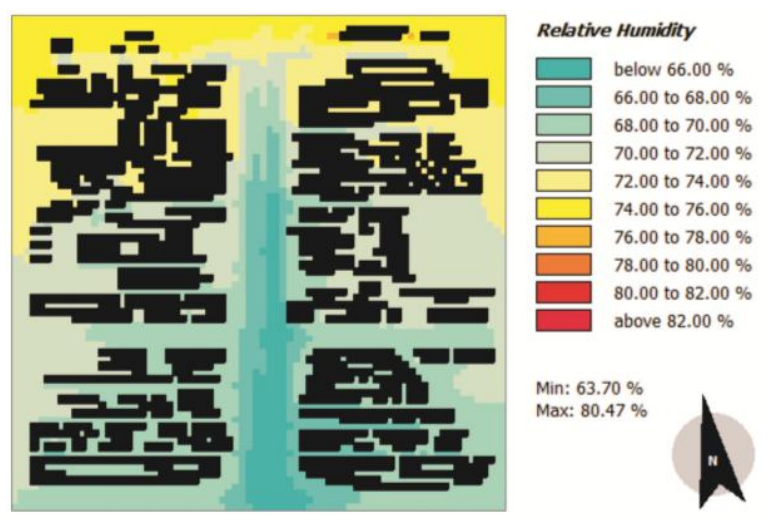

Fig. 5. Relative Humidity Simulation Results in Existing Conditions.

From the simulation of the existing condition of air temperature (Figure 4) and relative humidity (Figure 5) is very related when the air temperature is high then the humidity is low, and vice versa. In existing conditions, the air temperature in the northern part (Cik Ditiro street) is hotter than the southern part (Suroto street), it is marked by a more dominant red color in the northern part caused by the lack of vegetation in the northern part.

Furthermore, for the relative humidity in the southern part looks higher compared to the northern part marked with a more dominant green color, because in the southern part of the corridor is more vegetation than the northern part. So that if viewed based on air temperature, the air temperature in the southern part is lower than northern part. 


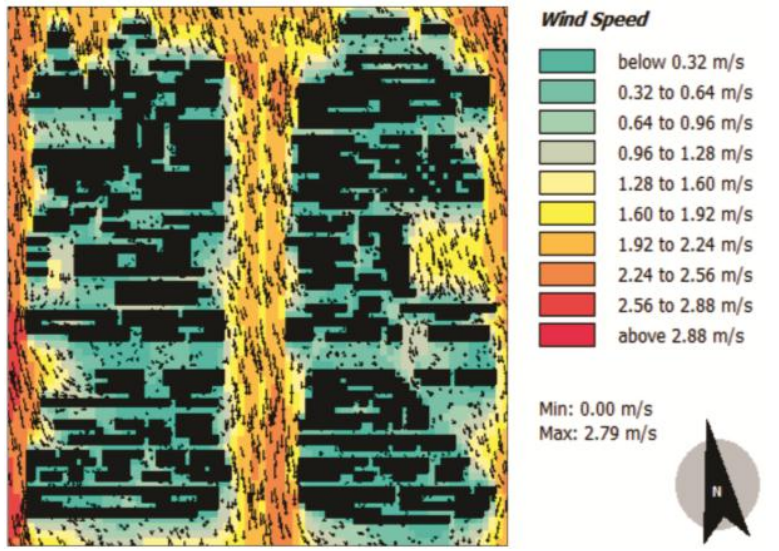

Fig. 6. Wind Speed Simulation Results in Existing Conditions.

From the results of wind speed simulation (Figure 6), building density greatly affects the wind speed. More tightly between buildings the smaller the wind speed passes, as well as vice versa. In addition, on the street which lack of vegetation as in the northern part the wind tends to be firmer than the southern part that many vegetations. In addition to functioning as a restraint solar radiation, vegetation can also restrain a strong wind speed.
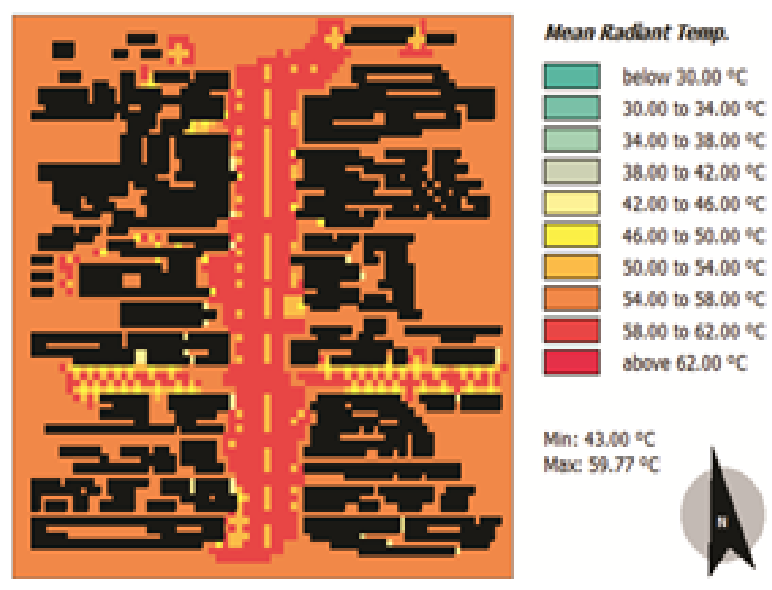

Fig. 7. Mean Radiant Temperature Simulation Results in Existing Conditions.

From the result of a simulation (Figure 7), Average Radiant Temperature in Cik Ditiro corridor is very high $43^{\circ}-59,77^{\circ} \mathrm{C}$ if averaged overall. When viewed based on the color in Figure 7, the dominant middle part is red is a place or point of importance on the Cik Ditiro corridor where humans do activities throughout the day as a user corridor. The red color, if viewed according to the legend, the average radiant temperature in existing condition is $58^{\circ}-62^{\circ} \mathrm{C}$. So that it can be interpreted that the average radiant temperature in Cik Ditiro corridor if categorized very hot, because the surface of the material in Cik Ditiro corridor is dominated by hard surface materials such as asphalt and paving. In addition, lack amount of vegetation causes solar thermal radiation can heat the asphalt and paving so that can raise mean radiant temperature in the corridor and impact on the ambient air temperature.

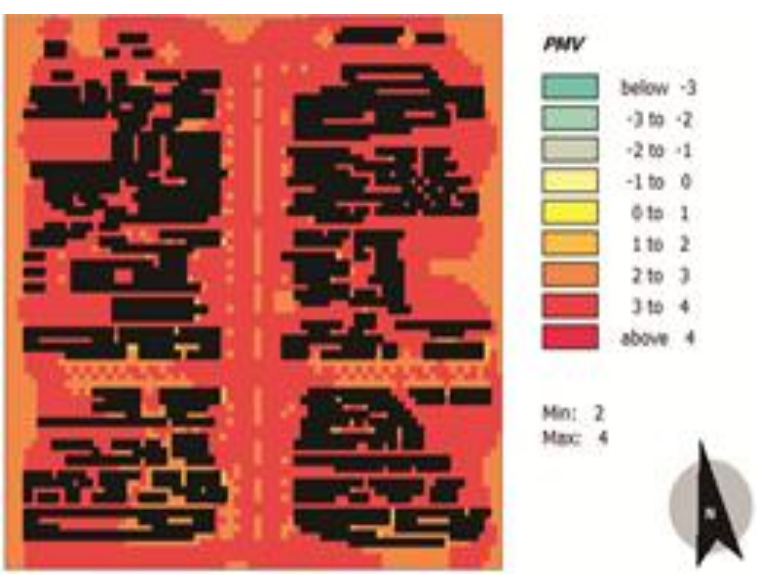

Fig. 8. Predicted Mean Vote Simulation Results in Existing Conditions

In the thermal comfort standard, there are 7 points scale from cold (-3) to hot (+3) (ISO 77401994). Based on the results of the simulation thermal comfort (Figure 8), the existing condition in Cik Ditiro corridor is in the hot category with thermal comfort value (+3).

\section{OPTIMIZATION SIMULATION OF THERMAL COMFORT IN CIK DITIRO CORRIDOR}

This simulation of thermal comfort optimization aims to provide basic reference in improving the thermal comfort in Cik Ditiro corridor. Before doing the optimization simulation, the first thing to do is modify the existing model. From the modification of the existing model, generates two optimization models (model 1 and Model 2). From the results of the two optimization models are expected to improve the thermal comfort in Cik Ditiro corridor so that it can support the corridor users especially the pedestrians in activities throughout the day.

On the model 1, modifications made are changing from existing condition in a simple and efficient way. This Model 1 only increases the number of vegetation by doubled from the existing condition. The addition of this vegetation to know how large the impact of temperature degradation in the area, as mentioned in some previous research of vegetation is important in decreasing air temperature to reach thermal comfort. 


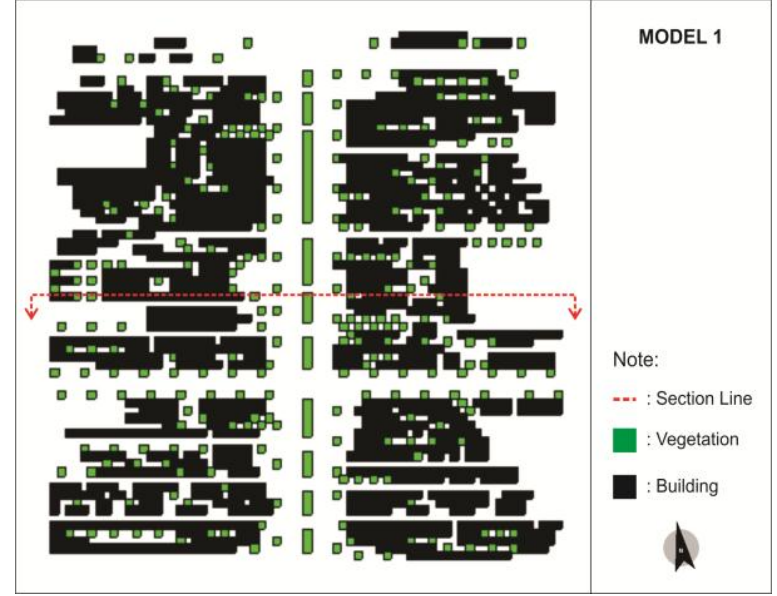

Fig. 9. Top View of Optimization Model 1 of Cik Ditiro Corridor.

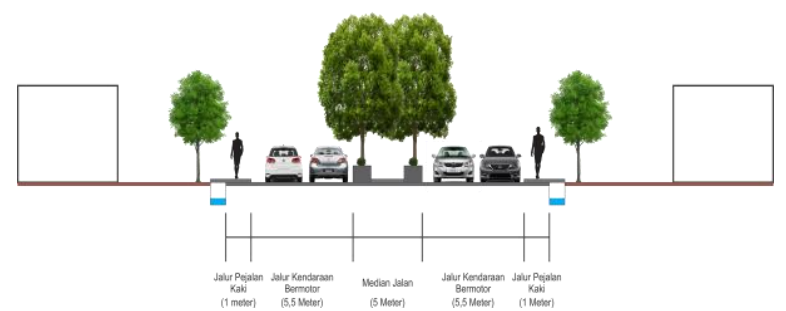

Fig. 10. Section of Optimization Model 1 of Cik Ditiro Corridor.

In the design of model 1 as in figure 9 and figure 10 , this design is applied continuously from Cik Ditiro Street to Suroto Street. As mentioned earlier, in Model 1 design is only the addition of vegetation as much as doubling of existing condition.

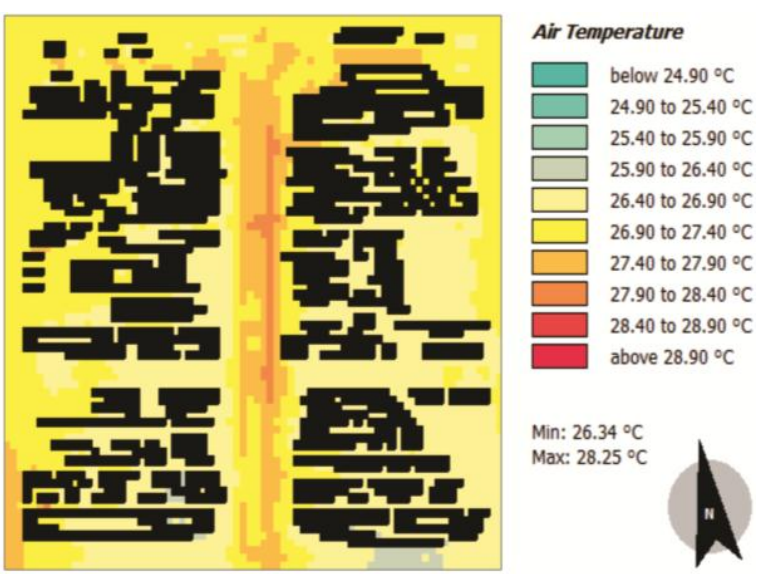

Fig. 11. Air Temperature Simulation Result of the Optimization Model $1\left({ }^{\circ} \mathrm{C}\right)$

From the optimization simulation of model 1 (figure 11), the air temperature changes in the northern part to the southern part. The air temperature on Cik Ditiro corridor decreased about $1^{\circ}-2^{\circ} \mathrm{C}$. This proves that vegetation can affect the decrease in air temperature in the area.

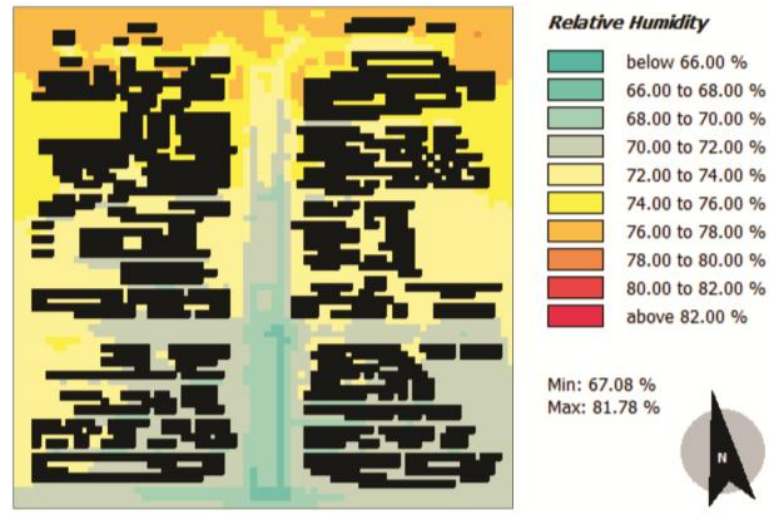

Fig. 12. Relative Humidity Simulation Result of the Optimization Model 1 (\%)

Furthermore, the result of the optimization simulation about relative humidity on the model 1 (figure 12), relative humidity on Cik Ditiro corridor rise about $3-4 \%$. Compared with existing conditions, relative humidity in this model 1 rises due to the addition of vegetation.
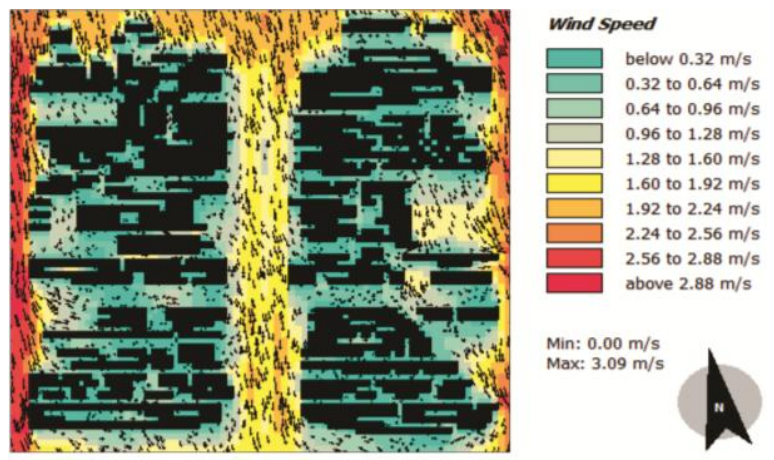

Fig. 13. Wind Speed Simulation Result of the Optimization Model $1(\mathrm{~m} / \mathrm{s})$

From the optimization simulation on Model 1 (Figure 13), showing the wind speed on the model 1 decreased 1 - 2\% compared to existing conditions in Cik Ditiro corridor. This is because vegetation can withstand the wind speed.
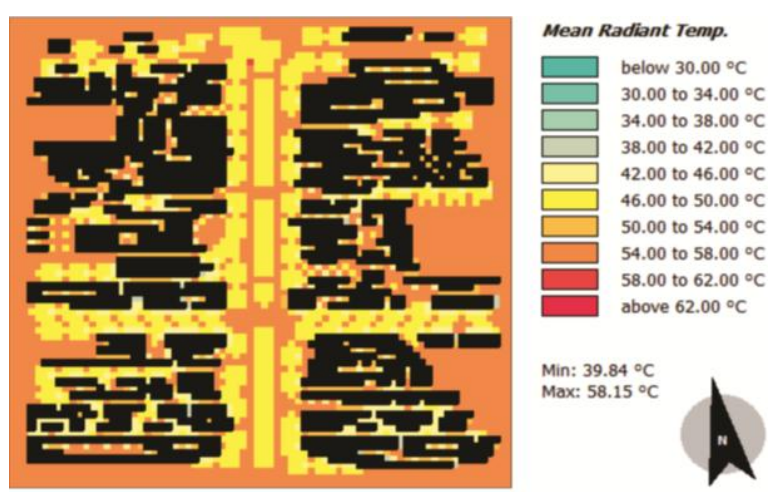

Fig. 14. Mean Radiant Temperature Simulation Result of the Optimization Model $1\left({ }^{\circ} \mathrm{C}\right)$ 
According to the optimization simulation of mean radiant temperature on the model 1 (Figure 14), it shows that mean radiant temperature on the model 1 if the overall averaged decreased by $2^{\circ}-3^{\circ} \mathrm{C}$ compared to the mean radiant temperature in existing conditions Cik Ditiro Corridor. In this model 1, the function of vegetation in the form of trees is very important in lowering mean radiant temperature. Because the trees can inhibit solar thermal radiation against hard surface materials.
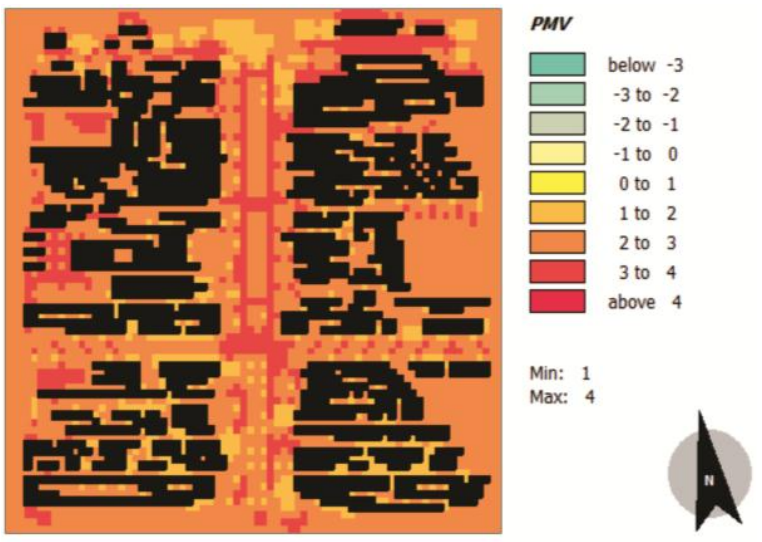

Fig. 15. Predicted Mean Vote Simulation Result of the Optimization Model 1 (PMV).

Figure 15 is the result of optimization simulation to determine the thermal comfort of the Cik Ditiro corridor. This result is determined by the unit value PMV (Predicted Mean Vote). If viewed from the color indicator in the simulated results, the orange color is more dominant in this model 1 . This orange color has the value PMV (+2). Then if categorized based on predicted mean vote index, PMV value (+2) means it has a hot thermal sensation.

From total of optimization simulation that conducted on this model 1 , modifying the existing condition of Cik Ditiro corridor by adding the amount of vegetation doubling can give a positive impact in terms of reaching thermal comfort. However, the results of the optimization simulation on this model 1 are still lacking, because the thermal comfort value (PMV) is still far from the ideal value of thermal comfort (0). Therefore, the next thing is to modify the existing condition to be Model 2 in optimization simulation. After that, optimization simulation results on this model 2 will be compared with model 1 and existing model.

In this model 2, there are some modifications made among others, the addition of vegetation in the side of the roadway, the yard and the vacant land in Cik Ditiro corridor that in total reaches five times the existing condition. Then the reduction of the hard surface material as asphalt in the roadway is replaced with greenery so that it is expected to reduce the volume of motor vehicles through Cik Ditiro corridor. In addition, the reduction of motor vehicles volume which conducted so as to reduce the heat from motor vehicles, because the heat of the motor vehicle contributes more in affect to rise up of air temperature in Cik Ditiro corridor.

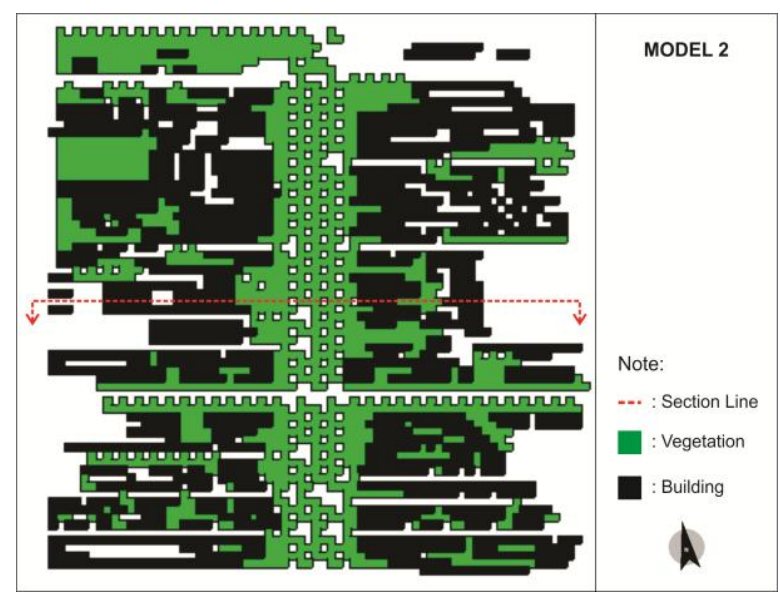

Fig. 16. Top View of Optimization Model 2 of Cik Ditiro Corridor.

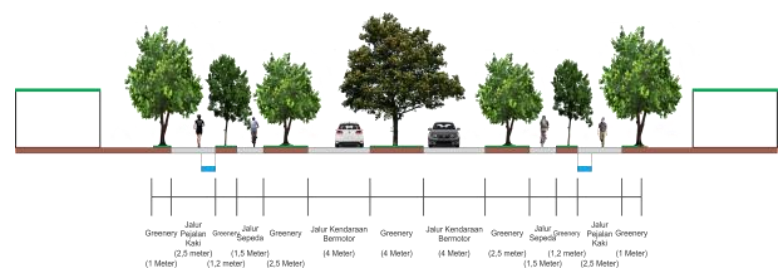

Fig. 17. Section of Optimization Model 2 of Cik Ditiro Corridor.

Adding the width of a pedestrian way and adding a bike lane on this model 2 is expected for motorists who can switch using bicycles. Replacing the color on hard surface material such as asphalt and paving block from dark to bright color is expected to reduce the absorption of solar heat during the day.

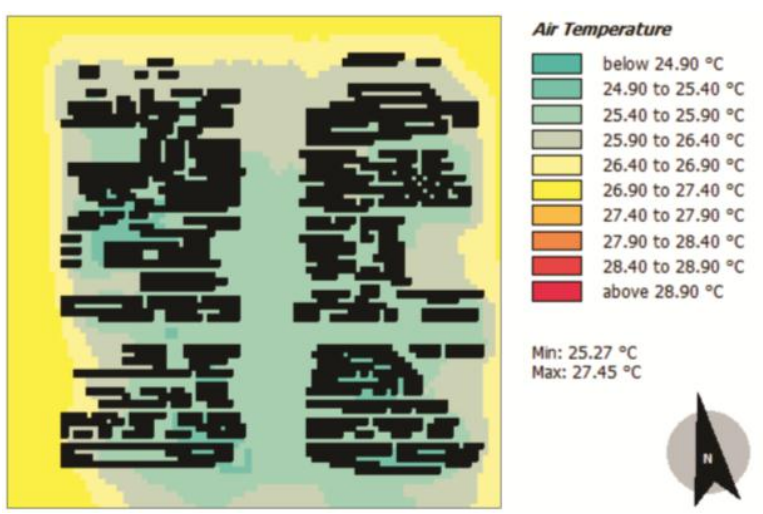

Fig. 18. Air Temperature Simulation Result of the Optimization Model $2\left({ }^{\circ} \mathrm{C}\right)$ 
From the optimization simulation of model 2 (figure 18), Air temperature in this model decreased by $2^{\circ}-3^{\circ} \mathrm{C}$ compared to existing conditions. Several things cause the air temperature in this model decreased as in the addition of vegetation that serves as a restraining radiation of solar heat so that the air temperature can be stable. In addition, reducing the area of the hard surface material and by changing the color from dark to bright can also reduce the absorption of the solar thermal radiation during the day.
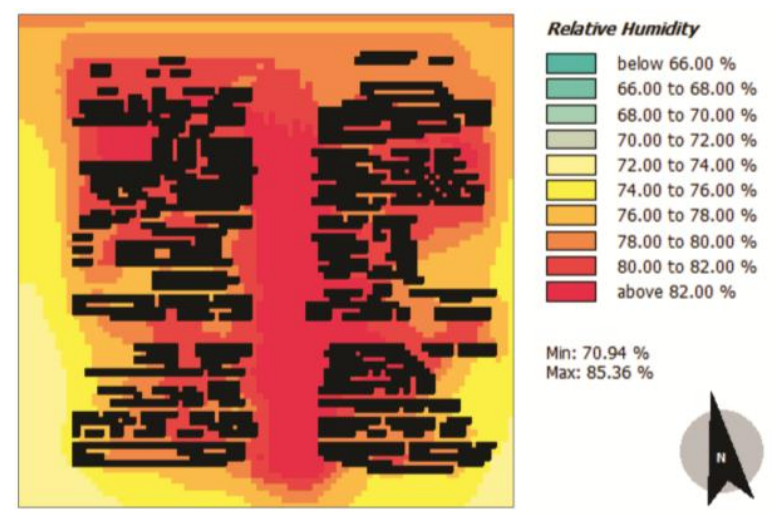

Fig. 19. Relative Humidity Simulation Result of the Optimization Model 2 (\%)

If viewed based on the visualization of optimization simulation results (Figure 19), relative humidity in this model 2 looks increased compared to existing conditions. This relative humidity increase is due to the effect of vegetation that keeps relative humidity on this model 2 . If based on the relative humidity unit value $(\%)$, relative humidity in this model 2 increased by $8-10 \%$ compared to existing conditions.
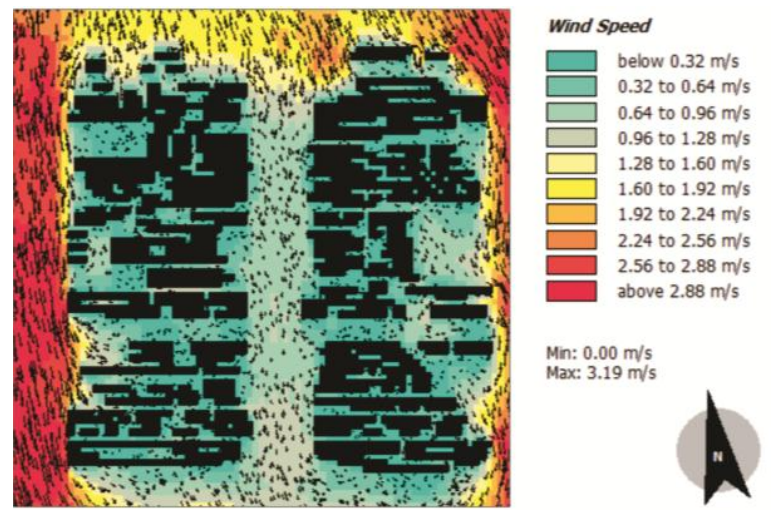

Fig. 20. Wind Speed Simulation Result of the Optimization Model $2(\mathrm{~m} / \mathrm{s})$

From optimization simulation results on the Model 2 (Figure 20), wind speed on this model decreases compared to existing condition. Wind speed on this model 2 is still in comfortable category in humans. Wind speed decreases due to the addition of more vegetation than the existing condition so that the vegetation can restrain the strong wind flow. On the other hand, this decreasing wind speed increases the humidity because the water vapor carried by the wind decreases.

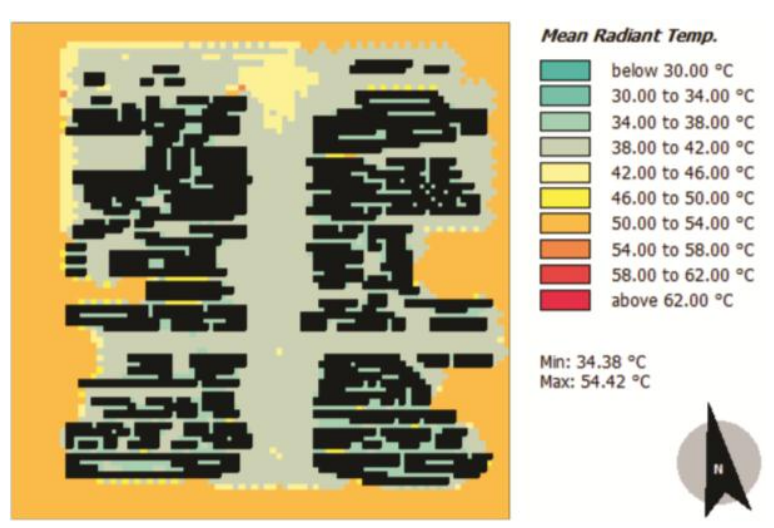

Fig. 21. Mean Radiant Temperature Simulation Result of the Optimization Model $2\left({ }^{\circ} \mathrm{C}\right)$

According to the optimization simulation of mean radiant temperature on the model 2 (Figure 21), it shows that mean radiant temperature on the model 2 if the overall averaged decreased by $6^{\circ}-8^{\circ} \mathrm{C}$ compared to the mean radiant temperature in existing conditions in Cik Ditiro Corridor. This is due to area reduction of the hard surface material and color replacement of the material can reduce the temperature of the radiation from the solar heat. In addition, the laying of vegetation in the form of tree in a tightly each other can also function as a solar radiation inhibitor that falls to the hard surface material.

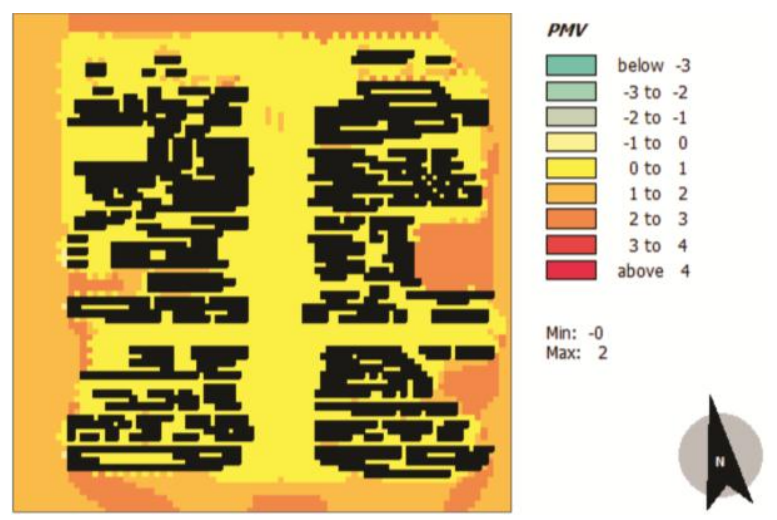

Fig. 22. Predicted Mean Vote Simulation Result of the Optimization Model 2.

Thermal comfort of this model 2 can be said to be much better compared to existing condition in Cik Ditiro corridor. Just like in the results of the 
optimization simulation of the previous thermal comfort, this result is determined by the unit value PMV (Predicted Mean Vote). If viewed from the visualization of simulated results in Figure 22, the PMV value on this model 2 has reached a value of 0 . This PMV 0 value, if interpreted by the Predicted Mean Vote (PMV) index (ISO 7740-1994), has a neutral thermal sensation in which it is the ideal value of thermal comfort in humans.

From total optimization simulation that conducted on this model 2 , modifying the existing condition of Cik Ditiro corridor by adding the number of five-fold vegetation can give a positive impact to reach thermal comfort for Cik Ditiro corridor user. It is characterized by decreased and steady air temperatures, rising relative humidity and decreasing mean radiant temperature. In addition, the reduction of the hard surface of the material and replacing the color on the hard surface of the material from dark to bright can also help in reducing the temperature absorption of solar radiation that can affect the rising air temperature surrounding the area.

\section{COMPARISON OF SIMULATION RESULTS}

After a simulation of existing models, model 1, and Model 2, the next thing is to compare from the whole simulation to the comparison chart. The purpose of this comparison chart is to know how much change is happening from each model that has been simulated.

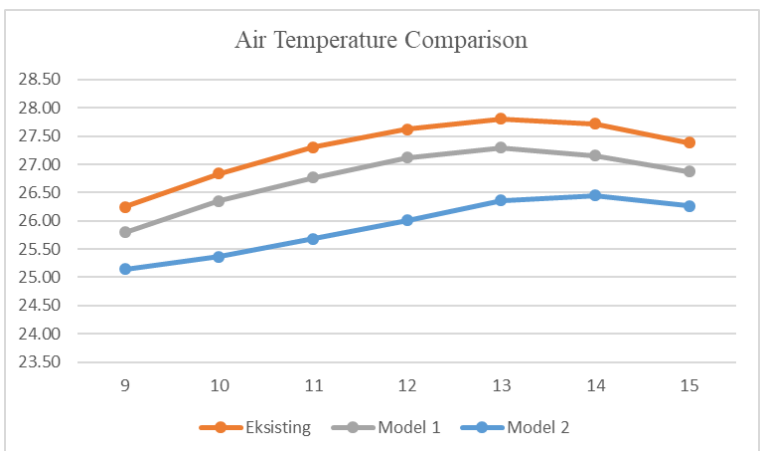

Fig. 23. Air Temperature Comparison Chart $\left({ }^{\circ} \mathrm{C}\right)$

From the air temperature comparison chart in figure 23 , there are differences occurring from each of these models due to several factors such as the number of vegetation and the area of the hard surface material. In existing models, lack of vegetation such as trees make this model has the highest temperature of air compared to model 1 and model 2 . Furthermore, on the model 1 with modifications added the number of vegetation such as trees have a lower air temperature compared to existing models.
The lowest air temperature is in the Model 2, this model is modified by the combination of adding the number of vegetation, reducing the area of the hard surface of the material and replacing the color on the hard surface material from dark to bright. From the combination of such modifications make this model 2 has the lowest air temperature compared to the temperature in the existing model and model 1.

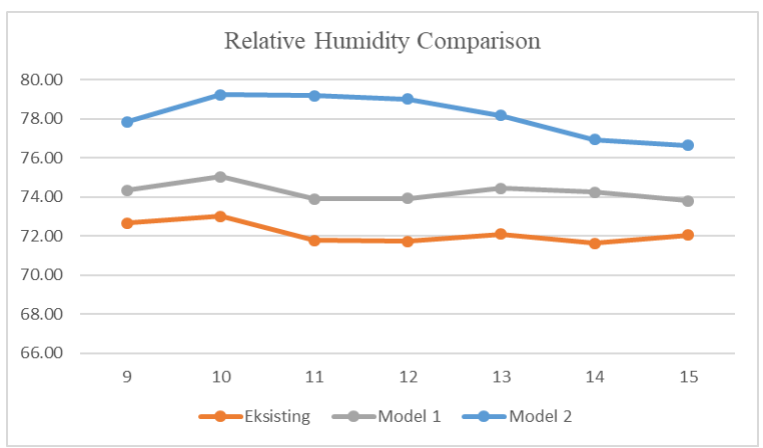

Fig. 24. Relative Humidity Comparison Chart (\%)

Vegetation has an important role in increasing the relative humidity in an area. As in existing models with lack of vegetation has relative humidity that tends to be low compared to model 1 and model 2 . When the number of vegetation is added to the model 1 and model 2, the relative humidity becomes increased (Figure 24). However, in the model 2 by adding more vegetation compared with existing models and model 1 , result of relative humidity in this model 2 is the most high among others.

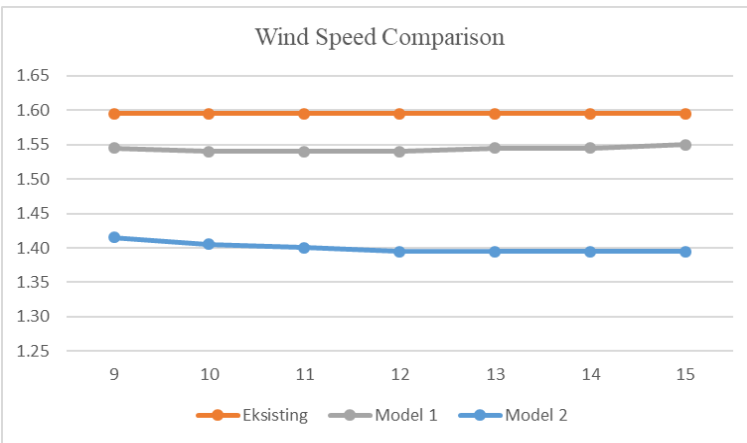

Fig. 25. Wind Speed Comparison Chart (m/s).

From the wind speed comparison chart (Figure 25 ), the wind speed in existing condition is higher than that of model 1 and Model 2. This is due to the lack of wind barriers like trees on existing conditions. The result of wind speed simulation, the lowest wind speed is on the Model 2. This is due to the addition of more trees than the existing model and model 1 with a tight tree layout that makes the wind can be restrained. However, the low condition of wind speed on this model 2 is still quite comfortable in humans. 


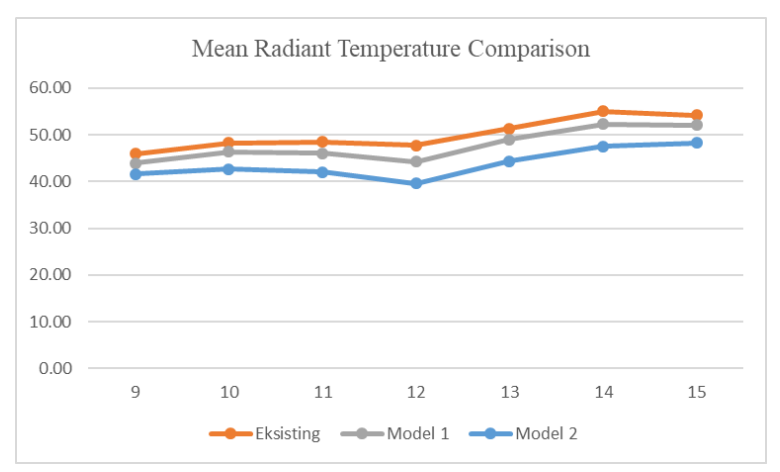

Fig. 26. Mean Radiant Temperature Comparison Chart $\left({ }^{\circ} \mathrm{C}\right)$

In mean radiant temperature comparison chart (Figure 26), the highest mean radiant temperature occurs in existing models. This is due to the lack of vegetation such as trees that serve as withstanding radiation from solar heat to the hard surface of the material, and other causes are the larger area of the hard surface material compared to area of the soft surface material.

Simulation results of Model 1 with only the addition of trees able to lower the mean radiant temperature but not significant. Different from existing model and model 1 , in simulation result of model 2 has the lowest mean radiant temperature result. This is because modifications to the Model 2 are conducted by combining two elements that affect the mean radiant temperature changes such as the addition of vegetation, reduce the area of the hard material surface and replaced with soft surface material like greenery; change the dark color to a bright color on the hard surface material. From the modification of the two models (model 1 and Model 2), each has an important role in the rise and fall of the mean radiant temperature in the Cik Ditiro corridor.

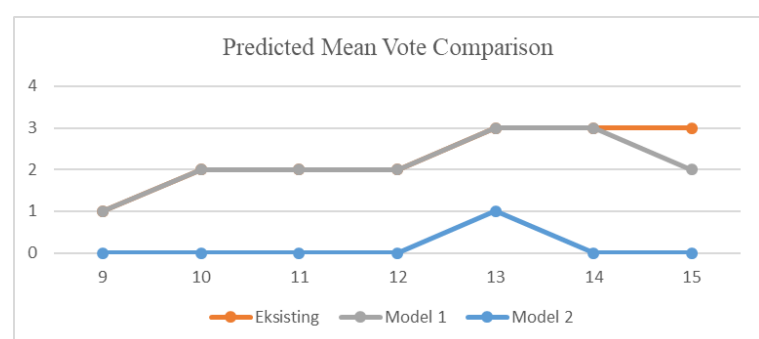

Fig. 27. Predicted Mean Vote Comparison Chart

As mentioned earlier, the value of thermal comfort in this study uses the value of PMV (Predicted Mean Vote). Based on a PMV values comparison chart (Figure 27), it is visible on existing models and model 1 has an almost identical PMV value starting at 09.00 until 14.00. However, in Model 1 there is a decrease in the PMV value when 14.00 until 15.00, while the existing model is still stable at the value of PMV $(+3)$. In these two models are also recorded to have a high PMV value at 13.00 and at 14.00 with the value of PMV (+3). The PMV (+3) value means it has a very hot on the thermal sensation according to the Predicted Mean Vote Index (ISO 7740-1994). Therefore, the conditions on these two models can be said to not reach the ideal thermal comfort for humans.

Furthermore, on the Model 2 have the best and stable PMV values compared to the other two models (existing models and model 1). If viewed on a comparison chart of the PMV value (Figure 27), the PMV value on this model 2 has reached the ideal PMV value (0) starting at 09.00 until 15.00. Nevertheless, when at 13.00 , the value of PMV on this model 2 rise to $(+1)$ which has the meaning warm in the thermal sensation (Predicted Mean Vote Index (ISO 7740-1994). The increase in the PMV value at 13.00 is not only in the Model 2, PMV value also increase on the existing model and model 1 . This is because the sun condition at the time is in the peak position (perpendicular) and the lack of radiation obstructions such as clouds become the cause of increased PMV value. However with the value of PMV (+1) which means warm in thermal sensation on this model 2 can still be said to be reasonable Considering the location of this research in Indonesia that has a that has a hot humid tropical climate.

\section{CONCLUSION}

Based on the overall thermal comfort simulation that has been conducted using EnviMET application, in the existing condition of Cik Ditiro corridor is still far from the ideal thermal comfort standard for human beings. It is based on the value of PMV (Predicted Mean Vote) which in this research is used as the final value in determining the thermal comfort. PMV value in the existing condition of Cik Ditiro corridor is very high and uncomfortable thermal if according to international Standard (ISO 7740-1994). There are several things that cause the high PMV value in existing conditions. Such as lack of vegetation, and the area of the hard surface material such as asphalt and paving larger compared with soft surface material such as greenery.

The changes have been made to reach the ideal thermal comfort value for human beings. As in the simulation result of model 1 modified by adding the number of vegetation, the results of PMV value on this model 1 slightly improved compared with the value PMV in existing conditions. However, the PMV value on this model 1 is still insufficient to fulfill the ideal thermal comfort standards for humans. 
Then, the results on Model 2, the PMV value is much more improved. In addition, has fulfilled the ideal thermal comfort standard, compared with the PMV value on the model 1 and existing model. On this model 2 was modified by combining the addition of vegetation and reducing the area of hard surface material such as asphalt replaced with soft surface material such as greenery and replacing dark color to bright color on hard surface material.

The conclusion of the overall simulation result on this research is that vegetation has an important role that can improve the thermal comfort of the region. The statement that vegetation is an important factor in improving thermal comfort has also been described in some previous studies (Karyono, 2013; Anupriya, 2016; Winansih, 2015; Koerniawan, 2017; Lee, 2018; Adedeji, 2011). Adding vegetation especially trees in Cik Ditiro Corridor besides can improve thermal comfort also serves as restoring the identity of Garden City in Cik Ditiro corridor. Furthermore, modifying hard surface materials such as reducing area and changing colors can also help in reducing heat absorption derived from solar thermal radiation and from the heat of the vehicle engine that can raise the ambient air temperature.

Ideal thermal comfort in the corridor of an area is one of the important factors to support human beings in conducting their activities in indoor and outdoor throughout the day especially during the day. If during the day the thermal comfort is far from standard/ideal then it can be ensured that human activity will be interrupted.

\section{REFERENCES}

Adityo (2016). Peningkatan Kenyamanan Termal Koridor Jalan Melalui Desain Tata Vegetasi Berbasis Simulasi, Jurnal Arsitektur KOMPOSISI, 11(3): 159-168.

Anindita, R. (2011). Kajian Kenyamanan Termal pada Jalur Pejalan Kaki di Kawasan Komersial, Studi Kasus: Jalan Affandi, Yogyakarta. Tesis. Yogyakarta: Universitas Gadjah Mada.

Adedeji, J.A. et al. (2011). Thermal Adaptation, Campus Greening and Outdoor Use in Lautech Campus, Ogbomoso, Nigeria. DIMENSI-Journal of Architecture and Built Environment, 38(2): 63-72.

ASHRAE (1992). Thermal Environmental Conditions for Human Occupancy. Standard 55-1992. Atlanta, USA.

Anupriya, S. (2016). Exploratory Study on the Relation between Urban Landscapes and Urban Corridors for Outdoor Thermal Comfort. Elsevier, Procedia Technology. 24: 1801 - 1807.
DISBANGOPSAU Bagian Meteorologi (2018). Data Klimatologi Kota Yogyakarta.

EPA (United State Environmental Protection Agency). Heat Island Effect Cooling strategies. http://www.epa.gov/heat-islands/heat-islandcooling-strategies. Accessed on February, 2019.

Fanger, P.O. (1970). Thermal Comfort Analysis and Applications in Environmental Engineering. Copenhagen : Danish Technical Press.

Girling, C. and Kellet, R. (2005). Skinny Streets and Green Neighbourhoods: Design for Environment and Community. Washington, Island Press.

ISO (International Standard) 7730. (1994). Moderate Thermal Environments Determination of the PMV and PPD Indices and Specification of the Conditions for Thermal Comfort. ISO: Geneva.

Karyono, T.H. (2001). Penelitian Kenyamanan Termis Di Jakarta Sebagai Acuan Suhu Nyaman Manusia Indonesia. Jurnal Dimensi Teknik Arsitektur, 29 (1): 24-33.

Karyono, T.H. (2006). Kota Tropis Hemat Energi: Menuju Kota yang Berkelanjutan Di Indonesia, Jurnal Teknologi Lingkungan, 7(1). Pusat Pengkajian dan Penerapan Teknologi Lingkungan, BPPT.

Karyono, T.H. (2013). Arsitektur dan Kota Tropis Dunia Ketiga, Suatu Bahasan Tentang Indonesia. Jakarta: Rajawali Pers.

Koerniawan, M.D. (2000). Kenyamanan Termal Rumah Susun Sederhana. Program Magister Arsitektur Fakultas Pasca Sarjana ITB. Bandung.

Koerniawan, M.D. (2017). The Climate Sensitive Design in Hot-Humid Urban Design. Dimensi, Journal of Architecture and Built Environment, 44(2): 137-142.

Koeningsberger, O.H., Ingersoll, T.G., Mayhew, A., and Szokolay, S.V. (1973). Manual of Tropical Housing and Building, Part One Climate Design. London: Longman.

Lee, I. et al. (2018). Analysis and Comparison of Shading Strategies to Increase Human Thermal Comfort in Urban Areas. Atmosphere, 9(91): 118.

Mingyi D.U, Weixian, SUN, and Yurong, CHEN (2008). Impact of corridor structure on urban heat island in Beijing, China. The International Archives of the Photogrammetry, Remote Sensing and Spatial Information Sciences. XXXVII. Part B8. Beijing.

Nikolopoulou, M., and Steemers, K. (2003). Thermal comfort and psychological adaptation as a guide for designing urban spaces. Energy and Buildings, 35(1): 95-101. 
Picot, X. (2004). Thermal comfort in urban spaces: impact of vegetation growth: Case study: Piazza della Scienza, Milan, Italy. Journal of Energy and Buildings, 36(4).

Spangenberg, J. (2004). Improvement of Urban Climate in Tropical Metropolis - A case study in Maracanã/ Rio de Janeiro". Thesis (Master in architecture), University of Applied Sciences, Cologne, Germany, http://www.basis id.de/ science.

Stevanus, R. (2015). Penataan Enclosure Ruang Jalan Komersial Sesuai Kenyamanan Termal bagi Pejalan Kaki, Studi Kasus: Jalan Raya Seturan (UPN-Babarsari). Tesis. Yogyakarta: Universitas Gadjah Mada.
Sugiono. (2016). Innovation of Building Design Based on Predicted Mean Vote (PMV) Index for Increasing Human Comfort. Dimensi, Journal of Architecture and Built Environment, 43(1): 1-8.

USDE (U.S. Department of Energy). (2009). Assessment of International Urban Heat Island Research: Review and Critical Analysis of International UHI Studies. USA: U.S. Department of Energy.

Wong, N.H and Ignatius, M. (2016). Urban Heat Island in Singapore: Contributing Factors and Mitigation Solutions. Innovation Magazine, 15(1): 33-39.

Winansih, E. et al. (2015). Thermal Comfort at the Street Corridor around Public Places, Case Study Alun-Alun Malang. Journal of Islamic Architecture, 3: 177-182. 